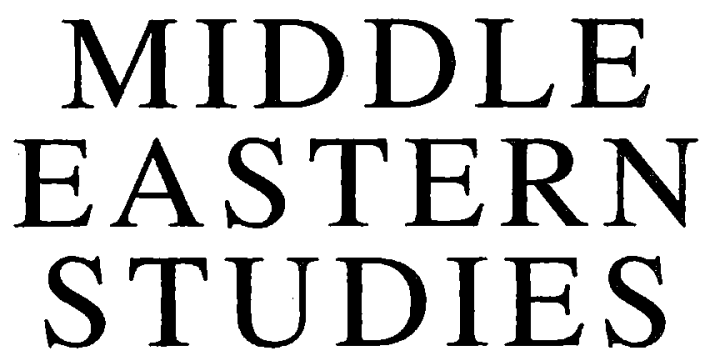

Volume 32 Number 2 April 1996 


\section{MIDDLE EASTERN STUDIES}

Founding Editor:

ELIE Kedourie

\section{Editor:}

Sylvia Kedourie

\section{Editorial Advisory Board:}

H. BOWEN-JONES

R.M. BURRELL

C.H. DODD

W.M. HALE

R.L. HILL

A. KeliDAR

A.K.S. LAMBTON
B. LEWIS

A. MANGO

R. TAPPER

C. TRIPP

P.J. VAtIKIOTIS

R. WILSON

M.E.'YAPP

Manuscripts and all editorial correspondence should be addressed to Sylvia Kedourie, 75 Lawn Road, London NW3 2XB.

Notice to contributors: Before commencing the final draft of their article, prospective contributors are advised to consult the notes at the back of the Journal.

While every effort will be made for the safe keeping of manuscripts and articles, the Editors cannot accept responsibility for any damage or loss which may occur. Manuscripts are returned only if accompanied by a stamped addressed envelope (or International Reply Coupons). Authors should keep at least one copy of their article.

Books for review should be sent to Frank Cass \& Co. Ltd., Newbury House, 900 Eastern Avenue, London IG2 7HH. Tel: (0181) 599 8866; Fax: (0181) 599 0984; E-mail: info@frankcass.com.

Subscription orders and enquiries should be sent to the Journals Subscription Department, Frank Cass \& Co. Ltd., Newbury House, 900 Eastern Avenue, London IG2 $7 \mathrm{HH}$.

(C) Frank Cass \& Co. Ltd. 1996

All rights reserved. No part of this publication may be reproduced, stored in a retrieval sustem, or transmitted in any form, or by any means, electronic, mechanical, photocopying, recording, or otherwise, without the prior permission of Frank Cass and Company Limited.

Annual Subscription: Institutions $\$ 135.00(\$ 195.00)$ post paid;

Individuals $£ 45.00(\$ 65.00)$

Single issue price information supplied on request by Frank Cass \& Co. Ltd.

Published in January, April, July, October by

FRANK CASS AND COMPANY LIMITED

Newbury House, 900 Eastern Avenue,

London IG2 7HH, England 


\section{Contents}

The Last Chroniclers of the Mabeyn

S. Tanvir Wasti 1

Young Turk Assessments of International Politics, 1906-9

Hasan Ünal 30

Turkish Settlement and the Caucasus, 1918-20

Bülent Gökay 45

Western Defence Developments and Turkey's

Search for Security in 1948

E. Athanassopoulou 77

The Press and the Consolidation of Democracy in Turkey

Metin Heper and Tanel Demirel 109

Democratic Transition in Turkey, 1980-83:

The Impact of European Diplomacy

Ihsan D. Dağ 124

Liberalism, Democracy and the Turkish Centre-Right:

The Identity Crisis of the True Path Party

Ümit Cizre Sakallığlu $\quad 142$

Urbanization and Voting for the Turkish

Parliament

Aryeh Shmuelevitz 162

The Paradox of Turkish Nationalism and the

Construction of Official Identity

Ayşe Kadıoğlu 177

The Rise of a Spontaneous Synthesis: The Historical

Background of Turkish Popular Music

Orhan Tekelıoglu

194

The Turkish State Discourse and the Exclusion of

Kurdish Identity

Mesut Yeğen 216

Small Employers in. Turkey: The OSTIM Estate

Theo Nichols and.

at Ankara

Nadir Sugur 230

Correspondence

A.L. Macfie and Bülent Gökay 253 


\title{
The Rise of a Spontaneous Synthesis: The Historical Background of Turkish Popular Music
}

\author{
ORHAN TEKELIOGLU
}

The essential objective of the Turkish Republic might be described as the founding of a nation-state with a new concept of the Citizen, or rather developing a new culture for people; and this republic has always assigned a peculiar role to culture policies in the process of nationalization. During the crucial early years when the new state was being built and organized, the nation's leader Mustafa Kemal often spoke and wrote of this cultural process as East-West or West-East synthesis, an appealing and succinct expression which was also taken up by ideologues of the day, in particular by Ziya Gökalp who considerably influenced Mustafa Kemal's views during the founding years of the Republic. This synthesis is still considered to be a sine qua non for the development of modern Turkey.

The notion urgently attached to the idea of an 'East-West synthesis' dates back to the period of Tanzimat reforms, the political underpinnings of which were put into effect during the unionist movement.' The first element of the binary expression East-West referred to the nation's Ottoman past, and embraced all those non-Turkish elements that were considered as requisite for building along nationalistic lines; while the second stood for a cultural territory that had not yet been gained but which, it was felt, Turkey would inevitably become part of. This objective of cultural synthesis, which took in all the political and economic orientations of the Turkish Republic, was in a sense another name, a summation, of a quest for a new cultural identity that is still so keenly felt today. The Ottoman legacy was multi-cultured, with a multiplicity of cultural identities, and the project of synthesis aimed to replace it with a new national one embracing a single identity. As this project was presented as something mandatory, admitting of no compromise, it could only be implemented in an authoritarian manner. Imposed 'from above' under the control of a cultural elite, this project of mandatory East-West synthesis put its imprint on all policies relating to culture and art from the founding years of the Turkish Republic.

It is remarkable that, while in the political sphere the political rulers of the early Republic were compelled to enter into coalitions with certain members 
of the late Ottoman political elite, in the cultural sphere they refused any alliance with this group. Instead they pressed on, authoritatively, reshaping institutions teaching art and organizing their activities, with the aim of creating a new national elite in the cultural sphere. As policies and institutions were formed in terms of this synthesis for culture and art in general, and for music in particular (the subject of this study), the fledgling nation-state took pains to define its own cultural territory of taboo: the East. Behind the synthesis lay a three-pronged classification: West/Origin/East. It gave the elements with which union was sought (the West and the Origin) while also referring to the territory with which unification was absolutely taboo, the East. It was Ziya Gökalp who pointed to the West as the future of 'our new civilization', but while there was an orientation in this direction, the origin of the synthesis was not forgotten, 'the traditional culture of the Turkish folk'. ${ }^{2}$ The West, far from being a mere geographical description, was considered the domain of modernity and was therefore taken as a model, its putative value measured against an 'East' which was considered as standing for backwardness itself.

In particular, from the moment the Republic was founded, music was given pride of place in policies relating to culture and art, a kind of 'target' as leaders sought to fashion a new sort of citizen and a new nation-state. The first indication that the political elite was sensitive about music, and keen on westernising reforms in this field, came in 1926 when they closed down the Doğu Müzigi Şubesi (Oriental Music Section) in the Dârü' l-Elhan, a residue from late Ottoman days and the only official conservatoire-like institution where music was taught. ${ }^{3}$ As they increasingly gained power, the new elite in music sought to impose quickly their ideas of westernizing reform. In 1934, for example, a ban was placed on the radio broadcasting of Turkish music, even though there is uncertainty as to whether this meant all such music, or only that which was Ottoman in origin. ${ }^{4}$ In an effort to teach the people to enjoy polyphony, elegant light examples of Western music were played not only on the radio, but also in other public areas of life, for example on the vessels of the Turkish Maritime Lines and at government-sponsored ballroom dances. The radio ban on Turkish music lasted only twenty months, after which ever more of this music was broadcast, yet the Turkish Radio and Television (hereafter TRT) succeeded in replacing the ban with a much more comprehensive and enduring system of control, which was in fact, and still is, a censorship surveying both the musical form and textual content of music played on TRT frequencies. Meanwhile, as gifted musicians began to be sent abroad for training and education, a state conservatoire was founded, offering Western-style education and repertories. Orchestras performing polyphonic pieces offered the free of charge public programmes which incorporated easily digested Western classical music. Music classes, also free of charge, were to be had at the Halkevleri (People's Houses). 
What the new musical elite eventually hoped for was a birth, in the Turkish listener, of an enjoyment of polyphonic music which, it was assumed, the 'modern' western listener already had. The new cultural policies were built around the expectation that, with the gradual appreciation of polyphonic music, and the contributions of Turkish performers and gifted composers trained abroad, Anatolian melodies which came from and were beloved by the people, would be recomposed along polyphonic lines. In this way a West-East synthesis would be forged throughout the country, and a modern polyphonic Turkish art music come into being. Thus monophonic folk songs were cautiously collected by the special sections in the conservatoires but it is indeed TRT that played a notable role in the entire process, the melodies written down according to rules of western notation, and a system of classification developed and later in the 1960 s a peculiar radio station was set up (TRT 3) devoted entirely to the broadcast of polyphonic classical music, jazz and western pop music.

The cultural policies of the Turkish Republic on music, at least in its early years, included incessant surveillance of the music broadcast on that indispensable mass media the radio, as well as co-ordination with institutions formally training young musicians. But despite these efforts and control over the media, the people at large failed to appreciate the works of the polyphonic western and contemporary Turkish composers. The most startling development in music, however, from the perspective of the cultural elite, was the Arabesk, which emerged out of popular music in the late 1960 s and went beyond its status as a musical genre to become a way of life. The elitist effort to understand the Arabesk phenomenon was via a highly inadequate and external analysis in terms of simplistic problematic of social change, the migration to the urban centres and the rise there of gecekondu squatter towns." The problem with this approach was that it disregarded the inner dynamics of the musical discourse itself, attempting to reduce musical practice into the inescapable effects of social change. The Arabesk and Turkish popular music (hereafter TPM), which has now fused with the Arabesk both musically and emotionally, have experienced a rise among the population which can only be understood through the dynamics of internal change. These changes directly related to the musical discourse and at the ex-discursive social developments which surrounded them; the writings of Ziya Gökalp, state policies in the cultural sphere, the 'adaptation' decision by the authorities on the Arabic songs played in the Egyptian movies in the 1930s, the Democratic Party administration and its economic policies, the inner-migration and the gecekondu squatter towns, TRT 3, the Police Radio, the rise of a new elite and the new notion of understanding in the cities, and so forth. The rest of this study takes up both components of the discursive and ex-discursive dynamics of such unique interstructuration." 
Indeed, this piece attempts to discuss the collapse of one project of cultural synthesis, intrinsic in the cultural policies which were part of the Turkish Republic's objective of becoming a nation-state, and which may be termed as the imposed or West-East synthesis. Further, it is doubtful whether one can speak of another synthesis that has gropingly arisen to replace this, pioneered by the 'handicrafted' undertakings of certain musicians and perhaps best termed the spontaneous or East-West synthesis. Notice that in the evolution from an imposed to a spontaneous synthesis 'East' and 'West' change places on the axis (from West-East to East-West). The objective of this neologism is not to play on words, but to point to the direction of change that has taken place in the origin in question. The project that in everyday speech is rather carelessly referred to as an 'East-West synthesis was', at the beginning, in fact a 'West-East synthesis', as an examination of cultural policies under the Turkish Republic will reveal, especially during the early years. To phrase it slightly differently, this synthesis began with a model based on Western practices and forms. It may be perhaps for this reason that it has failed to undergo the transformation which has yielded the present-day synthesis we designate as 'East-West'.

To tell the truth, I am not especially fond of alaturka music. It makes you sleepy, and I prefer alafranga music, in particular the operas and operettas. And shall I tell you something? The modes we call alaturka aren't really Turkish. They were borrowed from the Greeks, Persians, and Arabs. And people say the drum and zurna [a kind of shrilled pipe] are specifically Turkish in origin, but I have my doubts. It seems that both instruments are really Arabic in origin. I once looked into the observations of an individual who had travelled in Turkistan, and who reported that the time-honoured instrument in villages there was the saz [long-necked fretted lute]. Here, too, in Anatolian villages they always play the saz.

Abdülhamit $\mathrm{II}^{7}$

There were two major types of music in Istanbul and Anatolia just before the founding of the Republic, and these can be considered under six categories. One may first refer to two basic sources: the music of the Ottoman Palace, and the music of the people. Closer examination indicates that the type of music performed especially for palace circles, Classical Turkish Art Music (hereafter CTAM), had two forms, formal and popular. In terms of its composers and performers CTAM was multi-cultural, while in spirit it was elitist and cosmopolitan. Performed in a solemn ritualistic way, the formal style - for reasons that became soon apparent - underwent, during the Republican period, a process of petrification and became an archaic genre. But leading musicians of the day (such as $\mathrm{Hacs}$ Arif Bey) were to single out the şarkı (song) from that tradition and paved the way for the rise of a popular 
style of CTAM, which later in the Republican period came to be known as Turkish Art Music (hereafter TAM).

Widely varying local traditions of rural folk music constituted the third category. After the breakup of the Empire, the Anatolian traditions of folk music were redefined and named Turkish Folk Music (hereafter TFM) according to the nationalistic tenets. The traditional music of tarikats (religious orders), yet another type referred to as Tekke Music (hereafter TM). TM was dealt a major blow and it essentially vanished except for the mystical music of Mevlevi origin, after the abolition of all tekkes and zaviyes (religious lodges and cloisters) immediately after the proclamation of the Turkish Republic. Eventually, amid movements towards westernization in the closing days of the Ottoman Empire, two types of music of Western origin came to occupy a distinctive marginal place in the overall scene. The best-known of these was Military Band Music (hereafter MBM) of the Ottoman Army. The other, found only in Istanbul, and at that marginally, was Kanto Music (hereafter $\mathrm{KM}$ ). $\mathrm{KM}$, as will be further discussed, was a very important source in that it became the first domain of spontaneous East-West synthesis in music under the republic.

Starting in its earliest days, the Ottoman State was always forced to take an interest in Western civilization and its technologies; but it was only in the waning days of the empire, when it began steadily to lose territory, that the movement towards westernization found support among the intellectuals and the ruling elite. It was in the area of technology that European powers first demonstrated their superiority, and their might was perceived in terms of consistent military victories over the empire. The first Ottoman institution to feel the impact of the West was the army, where an effort to restructure along European lines not only brought new technologies and new ways of doing battle, but also a scientifically-oriented, naïve positivistic system of thought and the realization of an urgent need to adapt to the requirements of the contemporary world. There is, indeed, no other explanation for the leading role assumed by the Army in westernizing and secularizing the country once the republic was founded. Particularly where music is concerned, it is not unanticipated that the Army of the Nizam-1 Cedid (the Army of the New Order, under Selim III) should wish to have a military band, that MBM with its marches should have been the preferred form of Western music. It is important to mention that 'soldier musicians' have always been influential and made the pioneering cadre of the Western-type musicians during the Republican period."

Music was traditionally accorded a place of honour in the Ottoman Army as exemplified by the Mehter band of the Janissaries. This band was maintained as an integral part of the army so that it would play music to lift the spirit of the troops as the army departed on military campaigns or before it engaged in battle. To the beat of the Mehter music, footsoldiers would slowly advance in 
the distinctive Janissary manner, two steps forward and one back. The first Ottoman orientations towards modernization took place in the army, as the order of battle, including step and formation, were reorganized in accordance with European military practice, while the marching tempo underwent a similar change. The Janissaries and Mehter Band, already out of favour for political reasons, suffered even further when the army was restructured. Musically speaking, the modernized army needed a beat to which the men could march in the newly-adopted Western manner, and Mahmut II, concealing his political aims, justified his elimination of the Mehters by pointing to the need for a European-style military band. In 1826 Giuseppe Donizetti, brother of the famous opera composer, was brought in from Italy, along with an assistant, to head the band that had already been created in the Army of the New Order. Donizetti was to serve for decades and ultimately receive the rank of Pasha, as he and other members of the band handled the problem of a limited repertory by composing marches in the Italian manner. The purpose of composing these marches was not so much to achieve a West-East synthesis as to supply various units of the new army with the kind of music they could march to. The major contribution of MBM, as far as the polyphonic composers of the Republican period were concerned, was in the area of notation. Indeed, not only were the marches written down, but also thanks to Donizetti's efforts, western-style notation was gradually adopted for music other than that played by the Army Band. Furthermore, the need for trained musicians to play in this band led to the creation, in 1833, of Saray Mizıka Mektebi (the Palace Military Band School), which was to constitute the nucleus of the western-style conservatoires later founded under the republic. Donizetti and his band had a definitive influence on the cultural life of the Palace, where they gave frequent concerts of polyphonic music; and famous European musicians visited the Ottoman palace and gave performances," while Dikran Çuhacıyan (1837-98) was educated in France and in 1875 wrote the first western-type opera composed in Turkey. Ever gaining in proficiency, the band musicians eventually formed the core of the Palace Symphony Orchestra, which in 1918, on the very eve of the Ottoman Empire's collapse, sent some eighty of its members on a highly successful tour of Europe."

Finally, KM deserves attention as a significant source-music. Although it came to exist during the last decades of the Empire in urban Istanbul only, and at that marginally at best, KM may nevertheless be considered as a primordial form of the spontaneous East-West synthesis which may be traced in today's TPM. This music, chiefly sung and played by non-Muslim minorities for entertainment, originated as an Italian song form (canzone), but it rapidly changed to take on a local character. In terms both of lyrics and performing style, KM was an example of how an East-West synthesis could take place in popular music, and its musical discourse provides important clues to help us 
understand the operetta form of the early republican years, as well as the gazino" culture (entertainment culture) which later mushroomed in Turkish cities.

[Here is music] to which one's response can be only cheap sentiment and a tendency to bow to fate. Ignorant of polyphony, which in the West was invented in the tenth century and was based on an effort of intelligence, this simple-minded, whining music represents at least a millennium of stagnation.

Ekrem Zeki Ün

At the twilight of the Ottoman Empire, there was, particularly among a handful of intellectuals, a storm bordering on hatred of the East and at the same time an admiration for the West bordering on adulation. Although a strong westernizing movement had already swept the empire, it was nevertheless only with the advent of the Turkish Republic that westernisation took the form of a consistent, carefully planned state policy. Having dealt successfully with his political opponents and achieved a secure position as the sole leader, Mustafa Kemal turned the face of the new republic towards the West, in terms of both development patterns and civilization modelling, setting into motion a series of reforms which, in a number of areas, were meant to bring about a West-East synthesis. His project was simply to introduce 'civilization' - Western civilization - into the Turkish Republic, and this objective was taken to be an absolutely mandatory one, defined within a positivistic framework and conceived as of a social engineering. One need only read Tank Zafer Tunaya, one of the most ardent and best known supporters of Kemalism, to see how naïvely positivistic were Mustafa Kemal's attitude as well as that his circle towards this programme of westernization, how deeply they believed that their objective reflected a 'universal truth'; to see, in other words; how mistakenly reassured they stood in their belief that Western civilization was superior to all others and that it could be the only civilization by which to set criteria.

Atatürk, or Kemalism, embraced Western civilization for a number of reasons:

1. No civilization is the creation of a single religion or people. It is the product of many peoples working together ...

2. Western civilization is the dominant one, in a sense the only one; for there is no other civilisation that can compete with it, none that is strong enough to resist it, none indeed that is equal to it ... since it is impossible to surpass it, the only alternative left is to join it. This is a matter of life and death, a matter of raising one's nation to a new level. It is a historical law that the East tends Westward.

Therefore, the Turkish revolution's unswerving decision is to enter the Western family, the family of civilization. ${ }^{2}$ 
The foregoing passage evinced how passionately Kemalist theorists pursued the 'imposed' West-East synthesis and how they thought 'modern civilisation' (that is, Western civilization) could be attained by means of that synthesis. If one examines the cultural policies which had such a peculiar place in the westernizing reforms of the republic, and in particular those reforms affecting music directly, one encounters Mustafa Kemal's speeches on civilization and music, and with the writings of Ziya Gökalp (1876-1924), who was unequivocally the most influential thinker, the leading ideologue, of his day. Gökalp's famous Principles of Turkism, published in 1923, depicts the philosophical background of the Republic's imposed West-East synthesis, and in a way constitutes a manual sketching out how, in his words, the fusion of the Origin with the West was to be executed. Gökalp considered the eventual success of nationalism to be closely connected with 'Turkish Civilization', which, he said, must advance at all costs; he spoke of how Turkish music could become truly national and actually outlined a programme for its future development. 'Before European music entered our lives', Gökalp claims, 'there were two types of music in the land. One was Eastern music, taken by Fârâbi from the Byzantines, the other was those Folk melodies that continued the tradition of ancient Turkish music'. ${ }^{13}$ Gökalp, then, argued that the elite music of the Ottoman Palace, representing the apogee of what Ottoman culture had achieved in terms of music, was essentially Byzantine, and he called it 'Eastern'. To reinforce his point, he returned to ancient Greek music, which, because it was based on quarter tones, he found 'artificial' and 'depressingly monotonous, in that it repeated the same melody over and over'. But, Gökalp argued, musical reforms during the Middle Ages in Europe went far to overcome the mistakes of Greek music, and opera went even further, giving rise to the 'civilized' Western music known today. However, the Eastern music which emerged from ancient Greek models, and which was played for centuries in the Ottoman lands, continued in its 'ill' state. The only 'healthy' music in Anatolia was TFM, which was enjoyed by the Turkish people at large. Thus Gökalp divided extant music into three classes (Eastern music, Western music, and Turkish Folk music) in order to pose this 'nationalistic' question:

Which of these, one wonders, is truly our national music? We have seen that Eastern music is not only ill, it is also non-national. Folk music is that of our national culture, and Western music is that of our new civilisation, so that neither of these is foreign to us. Thus our national music will be born from the fusion of our Folk music and Western music. Folk music has given us numerous melodies, which, if we collect and harmonize in the Western manner, will yield a music that is both national and European ... This, then, is in broad outline the programme 
for Turkism in the field of music. The rest is up to the lovers and creators of music in our nation. [My emphasis] ${ }^{14}$

Only if 'our national culture' welds with 'our new civilization' [the West], emphasized Gökalp, can one speak of a 'national music'. In other words, the problem and its solution have been defined as follows: the enemy is 'Eastern music', the soirce is 'Folk music', the model is 'Western music and its harmony', while the purpose is to achieve 'national music'. In Gökalp's idea of synthesis, besides two clearly defined types of music, there is an intriguing suggestion of a taboo concerning the abstract category of Eastern music, situated in 'the East', a mystifying, prohibited yet not clearly defined zone.

The programme for reaching the goal, on the other hand, reflects an astonishing lack of sophistication, possibly influenced by a naîve positivism: folk tunes are to be harmonized, using the methods of Western music, and made polyphonic. Here, Gökalp, a reader of oversimplified Durkheim, is evidently speaking the language of the western orientalist. As Ercument Berker has indicated, the model for synthesis considered by both Gökalp and Mustafa Kemal was a Russian one, for in the nineteenth century composers known as the Russian Five had followed such a path to achieve a 'national synthesis' in music. ${ }^{15}$

Music is partly a matter of taste, acquired simply through exposure or through a more formal route. In any case, Gökalp seems not to have been very familiar with Western music, while being an avid listener to Turkish folk music, and was consequently unencumbered as he sought to reveal the 'problem' and search for a solution. It seems that for Mustafa Kemal, a renowned Ottoman pasha and a member of the Ottoman political elite, it would not have been an easy matter to give up CTAM. Indeed, a number of sources, including Vasfi Riza Zobu's memoirs, demonstrate that Mustafa Kemal was very fond of this music, and that he even had his own ideas about how certain songs should be sung. Zobu relates the following strange anecdote:

Atatürk was fond of certain songs that were a product of the Ottoman capital, Istanbul, as well as the Rumelian folk songs, and he liked not only to listen, but to sing them ... Some works he sang in the accepted manner, but there were a few whose lyrics he especially liked that he would sing, bringing out the meaning of the words so that the emphasis of the music shifted, with some notes lengthened and others shortened, and some words sharply stressed, others much less so. An attentive listener would realize that the meaning of the words demanded such a treatment; that the composer had either not realized this, or had not considered the meaning important enough to affect his melody. Atatiirk insisted on remedying this neglect, singing to match the words, and 
demanding that a performer do the same; and if he or she had sung that song 'correctly' for many years, then the sudden change was too much to ask for. The performer would struggle, try to imitate Atatürk's rendering, and in the end meet with defeat ... These master musicians had no experience with acting, so in this matter they really had their work cut out for them. But with my training in drama, I would generally pass with flying colours, when Atatürk gave his exam in altering line and tone. [My emphases] ${ }^{10}$

This passage underscores a significant point of how the idea of a West-East synthesis in culture might be implemented by someone of Mustafa Kemal's clearly rather authoritarian stamp. Even more importantly, it suggests why the project might have been ill-fated to begin with and, indeed, how it might have been even recognized as an impossible one to achieve success for the time it was designed. Especially revealing in the final note of the passage depicting how master musicians were unable to bring about the desired 'reform', and that only an actor was able to succeed in reaping kudos, singing as if he were acting out a role. Also to be noticed, alongside the imposed mandate for change, is a sense of abruptness, a wish that the command be executed instantly.

Again in 1918, just before the War of Independence (1919-23), when Mustafa Kemal was in Karlsbad for treatment, he kept a diary in which certain remarks shed light on his approach to reforming music: 'Should I ever be in a position of authority and power, I believe I would bring about the desired reforms in our society with a coup. For unlike some others I do not think the views of the intelligentsia can gradually be brought around to match my vision: Indeed, my spirit rebels at the thought of acting in this manner.'" This coup d'état mentality, and its harshness, can be seen in the cultural policies of the Turkish Republic where they relate to music.

Ziya Gökalp's wishes and perhaps urgent haste, regarding an 'imposed' synthesis were largely shared by Mustafa Kemal, as reflected in his statements relating to music. It may now be argued that the project was merely impossible from the beginning. In any case, its failure meant that another synthesis would inevitably and spontaneously develop to replace it. In other words, the path laid out for music by the republic, and the role assigned to the listener, failed to gel, and syntheses ensued (such as the fantazi songs that appeared in the 1950 s, or the Arabesk of the late 1960 s itself) which the cultural elite had not expected and had failed utterly to comprehend.

As already noted, the Republic made its attitude towards traditional music clear when the teaching of Turkish music was banned in the Dârü' l-Elhan, where CTAM formed the core of the curriculum since the inception of that institution in 1917.18 The law that abolished the tekkes and zaviyes also dealt a 
fatal blow to TM, which occupied such a peculiar position in the wide array of religious music in general. Handed down as it was from master to apprentice, and dependent on the setting where ritual was carried out, this music could not hope to survive when the tekkes were abolished. In the repertoire of Münir Nurettin Selçuk, a pupil of some tekke musicians, commonly considered the last master of CTAM, the prominence of TM is noticeable. Behar makes in fact an important observation in underlining the linkage between Münir Nurettin Selçuk and the tekke musicians, who were forced to earn their living after the tekkes were closed by giving private lessons. ${ }^{19}$

It was in 1928 that Mustafa Kemal made his first public assessment of Turkish music. After listening to a concert of two groups who appeared in succession, one performing 'alaturka' the other 'alafranga' (possibly MBM), he claimed,

This music, this unsophisticated music, cannot feed the needs of the innovative Turkish soul, the Turkish sensibility in all its urge to explore new paths. We have just heard music of the civilized world, and the people, who gave a rather anaemic reaction to the murmurings known as Eastern music, immediately came to life ... Turks are, indeed, naturally vivacious and high-spirited, and if this admirable characteristic was for a time not perceived, that was not their fault. ${ }^{21}$

Thus Mustafa Kemal blamed the Ottoman intellectuals for their lack of awareness of the Turkish 'character', and accused them of forcing Turks to listen to a soporific music that ran contrary to their spirit. Eastern music, in other words, was not only anachronistic, but sedative at the same time.

In terms of cultural policy, the most significant proposal made by Mustafa Kemal is to be found in his opening speech to the parliament's 1934 sessions. Stressing that fine arts must be encouraged to advance without delay, he asked for rapid programme to be made in music, and continued as follows:

The measure of the change undergone by a nation is its capacity to absorb, and grasp, a change in music. The music which they are trying to get people to listen to today is not our music, so it can hardly fill the bill. We must not lose sight of this fact. What is required is to collect national expression that conveys fine thoughts and feelings, and without delay to put it to music following the most modern rules. Only thus can Turkish national music rise to take its place among the music of the world. ${ }^{21}$

The route was therefore open for cultural policies to make headway where music was concerned, and possible reforms were discussed at a meeting attended by eight renowned Turkish exponents of western music. One of these, Cemal Reşit Rey (1963), who in his memoirs narrated how, during the 
reform meeting, phone calls were repeatedly made from the Presidential Palace to ask how the music reforms were coming along. One participant was so overwhelmed by the pressure surrounding the proceedings that he actually proposed to have all singing of monophonic music banned in Turkey. This proposal was fortunately rejected, and an agreement reached on institutional reforms.

The year 1935 saw the founding of the Presidential Symphony Orchestra, while the following year the State Conservatoire was established. The first opera to be composed in the Republican period was $\ddot{O}_{z} s o y$, created by Ahmet Adnan Saygun on short order. The libretto, expressing the brotherhood of the Iranian and Turkish peoples, was reviewed personally by Mustafa Kemal. Two other operas, composed later (Bayönder and Taşbebek), were both unsuccessful and severely criticized in the semi-official newspaper, Ulus, by Burhan Belge, a close associate of Mustafa Kemal. ${ }^{22}$ Mustafa Kemal and his circle were not satisfied with the polyphonic Turkish works being composed in line with the expected synthesis, and so a new period began, one in which gifted musicians were sent abroad for education and training.

The most striking move was the radio ban placed on Turkish music, justified as having been inspired by a speech Mustafa Kemal made to open the Parliament. Announced on 3 November 1934, by the official Anadolu Ajansi (Anatolian News Agency), it lasted twenty months.." The leaders of the Turkish Republic have always placed great importance on radio broadcasts, and in the 1930s began the installation of powerful transmitters throughout Turkey. As a result, longwave broadcasts reached every corner of Anatolia, with receivers generally found in public places, such as coffee-houses, where the people could listen without any special effort. In 1935, the year Turkish music on the radio was banned, there were 8,082 registered receivers in Turkey, of which 3,244 were in Istanbul. ${ }^{24}$ When the ban was lifted, it was replaced by a much more comprehensive system of control, which was indeed a systematic form of censorship describing what type of Turkish music could be played on the radio, and later on TV.

In addition to the institutional censorship it exercised over Turkish music, TRT exerted influence on the musical policies of the Turkish Republic in a variety of ways that are worth considering. The most important argument of those defending the West-East synthesis was that TFM was a fundamental 'source' music; but for TFM to serve usefully as a source, it first had to be collected, written down, and classified. The newly opened conservatoire made serious efforts in this direction, and brought in foreign scholars, yet it was TRT that did the most of the collecting and classifying of TFM. The monopoly in radio broadcasting until the beginning of the 1990s meant that TRT was, for all practical purposes, the only broadcaster of TFM and CTAM. As for the insubstantial record industry, it preferred to market TAM and Western music, 
FIGURE I

THE HISTORICAL STRUCTURE OF THE 'SPONTANEOUS SYNTHESIS' IN TURKISH MUSIC

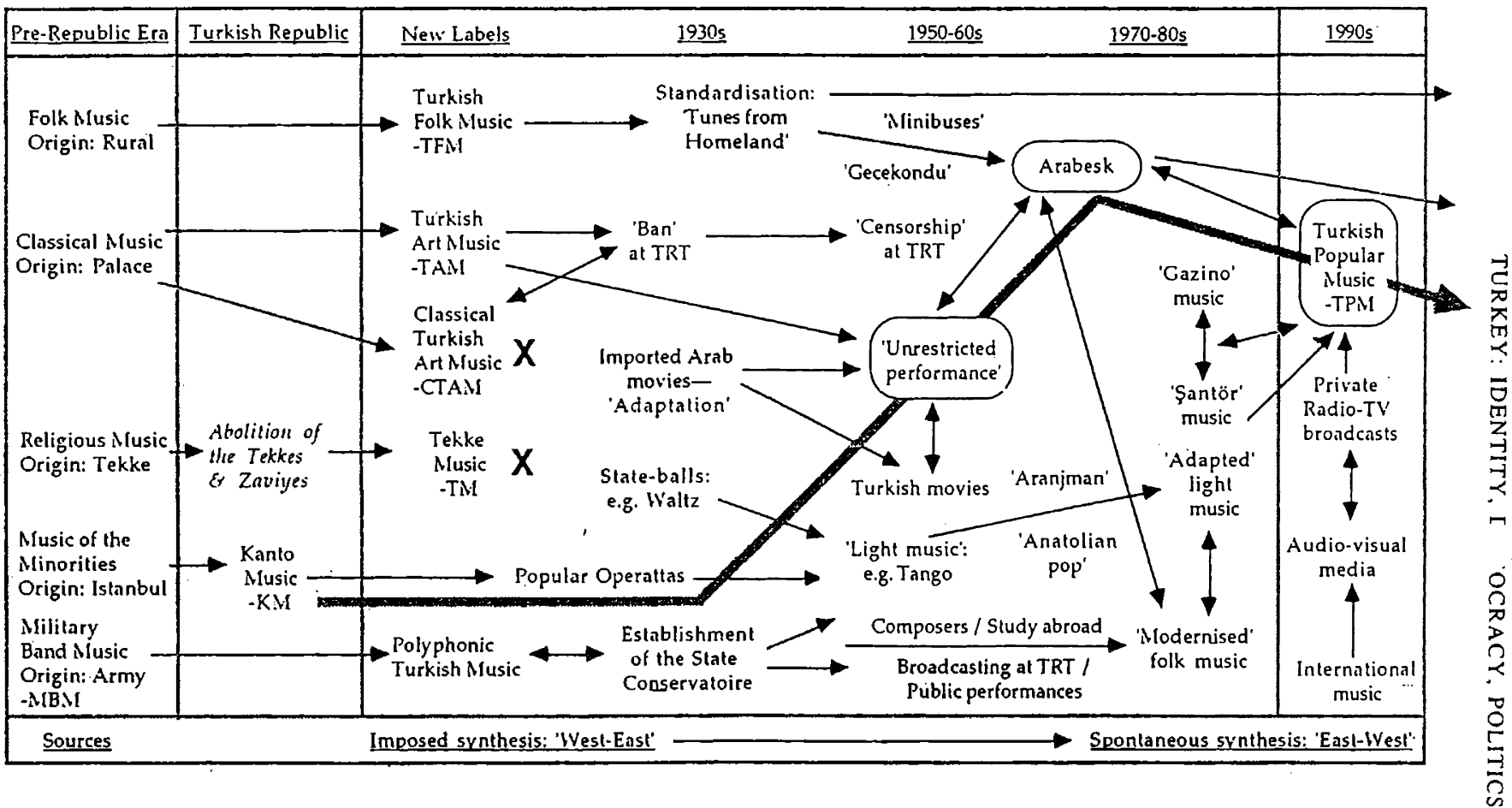


both popular in the cities, rather than TFM. TRT had personnel out in the countryside, as well as the necessary recording equipment, and especially while Muzaffer Sarısözen, a graduate of the conservatoire, headed the relevant department in TRT, the institution recorded hundreds of folk songs sung and played on the saz, by folk minstrels; and these songs were properly written down. In 1948 the collected and arranged folk songs began to be broadcasî on 'Yurttan Sesler' (Tunes from Homeland), a regular series of programmes destined to continue to the present day.

The unfortunate fact, however, is that 'Tunes from Homeland' is a prime example of how, even with the best intentions, cultural policies of the Turkish Republic during the founding years built around the notion of 'West-East synthesis' could be an obstacle to cultural change. In classifying and writing down the songs, the personal styles of the folk minstrels were not taken into consideration, even 'corrected' in each work by Muzaffer Sarõsözen to match a presumed general style of the local region in which it had been recorded. ${ }^{25}$ To reinforce this distortion, TRT instituted a practice which was utterly contrary to the tradition of these songs, having them sung by a chorus accompanied by a number of sazs, all, however, playing the same monophonic tune, with time beat out for the whole ensemble by a conductor. Someone must have thought that this was an application of western practice to TFM, with increased volume and a kind of 'orchestra' performance. 'Tunes from Homeland' is more than just a radio programme, it is a concrete application of the cultural policies, modelled from the West-East synthesis at their core, advocated by the musical elite of the Republic. As for an actual musical practice is concerned, it is a great misfortune that TRT, an institution of the state itself, succeeded in wiping out the traditional minstrel style in TFM.26

Meanwhile, CTAM was being, one might say, 'frozen' within the framework of a certain deliberate cultural policy, once again by TRT. Choral and instrumental programmes of CTAM-based music were broadcast at hours with the fewest listeners as if this music belonged to another age, as if it were an ancient form. Eventually it became textually incomprehensible and was forgotten. The only area in which TRT supported popular Turkish music was TAM, which it played on a regular basis, especially after the 1950s. Indeed, TRT actually trained performers of TAM, confirmation of a support for the genre which may seem inconsistent with the policies of West-East synthesis, but the main reason was straightforward: TRT did not want to lose its audience, and the interesting developments in popular music beginning in the 1930 s really left TRT with no alternative but to broadcast TAM.

Beginning in the late 1930 s, the State instituted a number of coordinated cultural policies in the field of music: Formal education in polyphony began in the conservatoires with Western educational institutions as model. Instructors were hired from abroad, as gifted students were sent abroad for training. 
Symphony orchestras began giving free concerts in various parts of the country. Both serious and popular works of polyphonic western music were regularly played on the radio. Courses in music were offered to the public free of charge in the Halkevleri (People's Houses), where both polyphonic music and standardized monophonic TFM were played. At 'State Balls' held for the public as well as for the newly forming political elite, dance music was selected from among light pieces such as waltzes, tangos, and the like. And in the school curricula, although there was little in the way of teaching the actual playing of instruments, rather extensive coverage of Western musical history and its composers were introduced into the curriculum.

But the Turkish listener at large hardly showed much interest either in the polyphonic music being composed by Turks, or in the western classical music that was being played. Instead, as a number of scholars have indicated, ${ }^{27}$ people began to tune in and listen to Arab radio stations playing. Arab music. Meanwhile the Turkish public also enjoyed the soundtrack of Arab films that had a substantial influence on the forming of new musical tastes. As a consequence, a significant and perhaps inevitable deficiency of the West-East synthesis policies in music began to emerge: no thought had been given to any polyphonic form of popular music, something which a broad segment of the people could enjoy and identify with. Perhaps the operettas, and the South American tangos with Turkish lyrics, could be cited as efforts in this direction, but the musical elite rejected these out of hand as being 'vulgar'. In any case, such music either quickly vanished or was marginalized (for example, the tango-inspired tunes with Turkish lyrics), or such popular operettas as Lüküs Hayat (The Posh Life) quickly took on a local character, as the canzone did and became 'kanto-ized'.

Given leaders who had been brought up and trained in a political milieu which was fundamentally elitist and based on a strong state tradition, and whose orientation was towards high culture, it is not surprising to detect authoritarian cultural policies imposed from above and which, ignoring the actual taste of the people, attempted instead to decide for them what they ought to like. ${ }^{2 *}$ What is nevertheless unexpected, and an instance of political blindness which deserves attention, is the failure to observe that these policies were not succeeding. Again, during the 1980s, when there was heated debate over the Arabesk, the same elite immediately dismissed the music as 'yoz' (degenerated). This, like the disrespectful term Arabesk ('Arab-like', i.e. a clone-type, non-original) itself, which was invented by intellectuals, can be considered as an example of the kind of 'short-sightedness' symptomatic of the elitist viewpoint in the Republican age. ${ }^{29}$

Due to its broadcast policy, TRT was compelled to be more pragmatic, but the decision to play TAM, which, it should be remembered, was growing ever more popular, may have expressed a wish to 'freeze' this type of music. 
Meanwhile, the TRT tactic, which may appear keen in the context of conditions then prevailing, indirectly opened the way for the imposed West-East synthesis to transmute into a spontaneous East-West synthesis, helping to awaken a remembrance of 'the East' in the collective memory of people.

CTAM consists of a number of musical forms which follow one another in a consecutive order, whereas TAM is the development of just one of these forms, the sark or song, or as one might call the Turkish lied. It seems that the first composer to popularize CTAM was Hacı Arif Bey (1841-95), the favourite composer of şarkı in the waning days of the Ottoman Empire. Owing to its musical structure, the TSM şarkı lends itself readily to popularization, for above all it is short, independent of other forms found in CTAM and composed as a song in its own right. No specialized background or training is required to accompany or appreciate it; the vocabulary is simple and readily intelligible and the 'message' is direct and easily comprehensible. Although the elite taste for CTAM began to erode in the late Ottoman period, when this genre gave early notice that it would evolve into TAM, the latter, and with it the şarkı, only became widely popular during the Republican years of the imposed synthesis. To summarize the argument made thus far, the two dominant factors affecting the development of music were, first, the effect of cultural policies forced upon music by the Turkish Republic, and second, the fact that there was no common ground between the music to which the people were traditionally accustomed and the music which authorities attempted to impose on them.

Far from being a mere 'offering to the ear', music is a whole world embracing many kinds of experience; it therefore managed to subsist in its popular forms even during the early years of the Republic. For urban dwellers one of the popular choices was the song (şarkl), another, kanto. Meanwhile, another interesting media development took place, effecting the development of music history in modern Turkey. By 1948, when Arab films were banned because of their possible political impact, some 150 of them (mostly from Egypt) had already been shown in theatres around Turkey. "These films, and their music, had become very popular - disturbingly as far as the authorities were concerned - so that in 1938 the import of Arab films as well as the playing of original Arabic lyrics were banned. This triggered a novel phase in the East-West synthesis of music, the practice of adaptation, in which the songs from Arab films were reworked: either the music remained unchanged and Turkish lyrics were dubbed in over it, or the whole song was redone with only a faint hint of the original themes that had served as the source of inspiration. In this way, employment opportunities arose for many skilled musicians from TAM who had found themselves mostly unemployed because of the government policies described earlier. During the time of adaptation, the most prominent name in TAM was that of Sadettin Kaynak." 
It would be Sadettin Kaynak who in the 1950s took the TAM genre known as serbest icra ('unrestricted performance') and moulded it in a fresh manner inspired by the Arab films of the 1930s and 1940s, giving Turkish music a type of composition style in TAM known as fantazi. Sadettin Kaynak (1895-1961) had an interesting background. Having been brought up in the tekke tradition, he was an ilahiyatçı (a graduate of the Islamic School of Divinity), he was often simply called 'hafiz', Muslim musician of cantor who could recite the Koran by heart. In the early years of the Republic, Kaynak was the most distinguished musician carrying on TAM in the tradition of Hacı Arif Bey, and in his adaptations from Arab films, he collaborated with Münir Nurettin Selçuk, and with a famed writer of lyrics, Vecdi Bingöl. This partnership not only gave rise to the highly popular fantazi songs, but more important, it led to a principal change in the musical 'taste' for the typical Turkish listener. Skilled musicians living in the urban centres and perpetuating the Ottoman musical heritage had then been compelled, by the government's cultural policies which excluded them, to popularize their work and - because of the form this popularized music took - to become the most significant obstacle, in the field of music, to the Republic's project of West-East synthesis." A further irony emerges that it was indeed TRT, charged with implementing state policies, which in broadcasting a 'controlled' version of TAM contributed greatly to the spread of this genre. It is unfair to blame TRT for such move, given the sheer fact that the listening audience had clearly shown its preference for TAM.

The 'unrestricted performance' approach initiated by Saadettin Kaynak became the most prevalent form of TAM beginning in the $1950 \mathrm{~s}$, and with the advent of Müzeyyen Senar, Zeki Müren ${ }^{31}$ and others, it became thoroughly entrenched. Meanwhile, the waves of social change brought on by the massive migration from the countryside to the urban centres meant there was a new audience for TAM, a non-elite audience with roots in the countryside, ready to take enthusiastically to 'unrestricted performance' in the urban setting of a gazino entertainment culture. At the same time the Turkish cinema developed a melodramatic tradition, its films, featuring either songs or singers,,$^{34}$ shown widely in Anatolia thus aiding on a long-term basis to spread 'unrestricted performance' to countryside and smaller towns.

What 'unrestricted performance' illustrates is less an insight into a musical East-West synthesis than into how a traditional genre can transform with a popular one. At the same time, however, 'unrestricted performance' implied a possibility of musical intervention into the method and interpretation followed during the act of composition. It represented an opportunity for free interpretation during the creation of a musical composition, with the TAM background of particular performers in mind. The awareness of such an opportunity may. have later significantly influenced the general approach of composers of 
Arabesk music, which was, after all, the first popular milestone in generating the spontaneous East-West synthesis. As Orhan Gencebay, the founder of Arabesk music, points out in his interview with Murat Belge, his project in the latter half of the 1960 s to develop a new genre of music (it would only later be given the name the Arabesk by pro-Western intellectuals) was undertaken with the 'unrestricted performance' experiences of the $1950 \mathrm{~s}$ in mind." It seems clear that, for Gencebay at least, the Arabesk project was a seriously conceived outlet for a TAM, which he saw as having stagnated in the $1960 \mathrm{~s}$, a project to introduce a new colour which he hoped would become popular. Besides that the Arabesk project included a highly important and original element which did not exist earlier in 'unrestricted performance': the instruments and the composing influence of western music.

As a result of westernization and the coming of age of republican institutions, urban listeners were presented new choices in popular music by the 1960s. The singing of popular European and American songs to Turkish lyrics, as observed earlier with the model of the South American tango, gave rise to A ranjman ('arranged') music, which was strongly supported by TRT. Indeed, TRT has even labelled the new genre as Türkf̧e Sözlü Hafif Müzik ('Light Music with Turkish Lyrics') and given it regular exposure on the air. Meanwhile another genre began to make itself heard on the urban centres: Anatolian Pop, created by more politically oriented musicians and designed to be a synthesis of TFM and Western music. ${ }^{36}$ One thing 'arranged' music had in common with Anatolian Pop was a use of the electronic instruments and polyphony found in western music. The greater range of volume obtainable by Western musical instruments in general, and electronic instruments in particular, attracted the interest of Orhan Gencebay and the Arabesk performers and composers who followed his lead. They also appreciated the sonorities which the western instruments could produce, sonorities not found in TAM. The electrosaz is the first original synthesis instrument to come out of the Arabesk, and hence out of the spontaneous East-West synthesis. What especially characterized the Arabesk, starting with the songs of Gencebay, was that western instruments, the electrosaz, extended strings, and sometimes a quasi-polyphony were used in the Arabic manner. The Arabesk music instantly found its way into the urban gazino culture, one of its branches featuring the electropiano alone, so that pianist-singers (piyanist-santör) were to be found in many clubs, cafés and restaurants. The Arabesk, in other words, was the first product of a spontaneous East-West synthesis gradually achieved through the efforts of certain musicians in TAM and one that became exceedingly popular, which is a musical success story in every sense of the word.

When it made its appearance on the scene, the Arabesk was instantaneously condemned by intellectuals and the culture elite as yoz (degenerate), and not a single example of it was broadcast by TRT which introduced a very strict ban 
on the Arabesk. Yet despite this government-backed counter-campaign it grew to be the only popular music of the $1970 \mathrm{~s},{ }^{3}$ and many popular performers had no choice but to make the Arabesk cassettes - from Zeki Müren of "unrestricted performance' fame, to İbrahim Tatlıses who had first captured the hearts of the public with his renderings of southeastern Anatolian folk songs. And a mere glance at the musical developments in the past decade could reveal that TPM and the Arabesk have been converging, predominantly in the direction of the Arabesk, so that one might speak of an Arabesk 'invasion' of the TPM discourse. The Arabesk flavour determines now what is to be called TPM: All the TPM hits always have an 'alaturka' melody, that the Arabesk singers (such as Emrah, the child star of Arabesk in the 1980s who, in the 1990s, changed his style and started to sing in the fashion of TPM) can sing Turkish Pop, and that the Arabesk singers like Ibrahim Tatlıses have gained acceptance at the highest level of government, sometimes being invited to perform at presidential receptions. At present the spontaneous East-West synthesis is enjoying its age of glory, in the form of TPM.

Music is a discourse made up of differing but related components (e.g. listener, performer, melody, lyrics, instrument, style, media) articulated together in a given conjuncture, time and space. The musical discourse is at the same time enveloped by ex-discursive practices which, though external to it, are related to it, defining its problematic and attempting to define the discourse itself. The present structure of the discourse of TPM can therefore not be adequately explained by reducing it to developments internal to this musical discourse; nor will it suffice to speak solely of the personal innovative skills of certain composers, or the peculiar taste of the performers, or the cultural policies surrounding the music, or social and economic changes during the Republican era. In other words, the Arabesk is, for instance, not the sole creation of Orhan Gencebay, nor 'the music of a society in transition', 'minibus music', or 'music of the gecekondu squatter towns'. Rather, the Arabesk is the sum total of all these and more, since it is a musical genre that was shaped within the inner dynamics of TAM from which it took rise. In the context of this essay, the concept of articulation signifies that the discursive and exdiscursive are interstructured in a particular way which is intrinsically linked to a certain history reference and a social territory. Only by recourse to such a concept of 'articulation' one may link the marginal musical discourse of KM to the popular musical discourse of spontaneous East-West synthesis which is today definitely TPM. KM enjoyed a marginal existence as entertainment music among the non-Muslim minorities in late Ottoman Istanbul, and was a spontaneous synthesis of the canzone with local colours and genres. The route by a series of transmutations then led via operetta, 'unrestricted performance' and the Arabesk to arrive at the present day TPM.

In summary, the marginal KM discourse was a kind of East-West synthesis 
which evolved into the popular TPM discourse of today. What was the exdiscursive phenomenon surrounding this transformation that mainly occurred in the musical discourse? It was none other than the set of cultural policies imposed by the leaders and governments of the Turkish Republic in music in the expectations of producing a West-East synthesis, a civilized version of Turkish music in the fashion of contemporary polyphonic music. The Turkish musical tradition, taste and musicians as well as the Turkish listener resisted with its own means and ultimately created its own synthesis, TPM. At the present time, with TRT's monopoly on broadcasting gone and TPM pouring out of the private radio stations and TV channels continuously, it is implausible that any form of high culture, elite music will rise in line with the West-East synthesis. Curiously enough, neither the pro-Western cultural elite could anticipate how the East-West synthesis would eventually come out, nor the musicians of the Arabesk and of the present TPM who actually created that new synthesis. There were, on the one hand, cultural policies which were imposed by the political powers that be, with the strong state adding its weight; and, on the other, a handful of skilled musicians and their ardent listeners with a traditional background passively resisting the cultural policies imposed from above. Yet it was something essentially 'alive' which had its roots in the cultural territory that was resisting something which was essentially 'expired' and this was enough to extinguish one synthesis and give birth to another. It is significant that this curious episodic socio-political history reflecting a national experience with cultural policies designed to reshape music is in fact an exemplary history of occidentalism - the twin notion of orientalism. ${ }^{\text {sk }}$ Moreover the occidentalism took place in the very 'orient' where the modernist rulers/elites would supposedly share after the strong belief in the supremacy of a Westem outlook on social life and culture.

And yet the question posed by Murat Belge some fifteen years ago still has a haunting ring: ${ }^{39}$ 'Had Turkey's traditional music been left to run its course freely, whether in the classical or the folk traditions, would it have reached a place so very different from that of today?'

NOTES

Abbreviations

CTAM Classical Turkish Art Music.

KM Kanto Music.

MBM Military Band Music.

TAM Turkish Art Music.

TFM Turkish Folk Music.

TM Tekke Music.

TPM Turkish Popular Music.

TRT Turkish Radio and Television Broadcasting Corporation. 
1. N. Berkes, The Development of Secularism in Turkey (Montreal: McGill, 1964), and also see S. Mardin, 'Religion in Modern Turkey', International Social Science Journal, Vol.23, No.2 (1977), pp.279-97.

2. Z. Gökalp, Türkçülügün Esaslan [Principles of Turkism], (Istanbul: M.E.B. Yayınları, 1990), p. 146.

3. G. Oransay, Atatürk ile Küğ [Atatürk and Music], (Izmir: Küg Yayını, 1985), p.l12.

4. U. Kocabaşoğlu, Şirket Telsizinden Devlet Radyosuna [From The Company Wireless to State Radio], (Ankara: S.B.F. Yayınları, 1980), p.82.

5. One should not mix the slum with gecekondu, a single-storey accommodation which has a higher building quality than that of the most slum examples from the third world. Gecekondu means 'put up at night'.

6. Because of the scale and various positions, the definition and the relevant discussions about the concept of discourse are not deliberately given. Related to the concept of discourse applied throughout this piece, one may however refer to the Foucauldian position. In this context, the essay focuses mainly on the inner dynamics of music as discourse and speaks of exdiscursive as the enveloping, overlapping and partly determining yet non-musical discourses.

7. B. Aksoy, 'Tanzimattan Cumhuriyete Musiki ve Batılılaşma' [Music and Westernization from the Tanzimat to the Republic], Tanzimat Dönemi Türkiye Ansiklopedisi, Vol.5 (Istanbul, tletişim Yayınları, 1985), p.1215. The notion in the quote alaturka does not simply signify 'alla turca' (i.e. in the Turkish way) but rather has a degrading connotation, which is a very common tendency among the pro-Westerners in Turkey. For the notion of alafranga (i.e. in the French [Western] way), the reverse connotation could prevail. Interestingly enough, the quote is from a Sultan of post-Tanzimat era. In the quote, there is also a reference to the Turkish instrument saz which is the most common instrument used in folks songs, and simply is long-necked fretted lute.

8. Hikmet Şimşek, for example, who for years has conducted the Presidential Symphony Orchestra, began his career in the Turkish Amy Band.

9. In 1847, for example, Franz Liszt paid a visit to the Ottoman Palace, where he performed.

10. The Palace Symphony. Orchestra, whose repertoire on the European tour included Beethoven's Violin Concerto, was conducted by Osman Zeki Üngör, who in early Republican years would compose the music to the Turkish National Anthem.

11. The gazino is a restaurant, operating at night where musical entertainment is offered, particularly by singers, and where meals are usually accompanied by the favorite alcoholic beverage, rakr. An altemative place to gazino entertainment is pavyon, offering cheaper entertainment and catering only for men.

12. T.Z. Tunaya, Devrim Hareketleri lç̧inde Atatürk ve Atatürkçülük [Atatürk and Kemalism in the Context of Revolutionary Movements], (Istanbul, 1964), pp. 120-21.

13. Z. Gökalp, Türkçülïgün Esasları [Principles of Turkism], (Istanbul: M.E.B. Yayınları, 1990), p. 145 .

14. Ibid., pp.146-7.

15. M. Belge et al., Atatürk Devrimleri Ideolojisinin Türk Müzik Kültürüne Doğrudan ve Dolaylı Etkileri [Direct and Indirect Impact of the Ideology of Atatürk's Reforms on the Turkish Musical Culture), (Istanbul: Bogaziçi Üniversitesi Türk Müziği Klubü Yayınları, 1980), p.34 and p.48.

16. T.Z. Tunaya, Devrim Hareketleri Içinde Atatürk ve Atatürkçülük. p.41.

17. G. Oransay, Atatürk ile Küg [Atatürk and Music], (Izmir: Küg Yayını, 1985), p.24.

18. Dârï' I-Elhan, a compound word meaning literally 'House of Tunes', was the first school of music in the modern sense and was founded in 1917 as an extension of the Istanbul City Theatre.

19. C. Behar, Klasik Türk Musıkisi Üzerine Denemeler [Essays on Classical Turkish Music], (Istanbul: Baglam Yayınları, 1987), p.138.

20. G. Oransay, Atatürk ile Küg, p.24.

21. Ibid., p.26;

22. Ibid., p.32.

23. The item is as follows: Ankara (A.A.) - The Ministry of Internal Affairs reports that today in the Grand National Assembly, inspired by the illuminating statements of the Gazi (Mustafa 
Kemal) per alatarka music, such music will be completely removed from the airwaves as of tonight, with perlormance there to be entirely in the hands of artists having mastered Western technique. G. Oransay, Atasürk ile Kïğ, p.49.

24. U. Kocabaşoğlu, Şirket Telsizinden Devlet Radyosuna, p.55.

25. Z. Livaneli. 'Yunus Emre'den Ferdi Tayfur'a' [From Yunus Emre to Ferdi Tayfur], Cumhurivel (15 Feb. 1980).

26. The Alevi 'minstrel' tradition was much less damaged by TRT's practices in collecting and notation, and indeed has survived to the present day. This may be connected to the fact that the Turkish Republic is a secular state, and that this is reflected in its policies toward religion.

27. M. Stokes, The Arabesk Debate. Music and Musicians in Modern Turkey (New York: Oxford University Press, 1992), p.93, and also see, N. Güngör, Arabesk. Sosyokültürel Açukm Arabesk Mitzik [Arabesk. A Sociocultural View at Arabesk Music), (Ankara: Bilgi Yayınları, 1990), p.55.

28. M. Heper. The State Tradirion in Turkey (Beverley: Eothen Press, 1985).

29. During the 1930s, when musical reforms were most outrageous, the musical elite had a number of names for CTAM like 'Monophonic City Music', 'Byzantian Action'. 'Music of Ottoman Palace'. 'Music of Drinking House', all intended to disparage it.

30. M. Özbek, Popüler Kültür ve Orhan Gencebay Arabeski [Popular Culture and Orhan Gencebay"s Arabesk ], (Jstanbul: Iletişim Yayınları, 1991), p.154.

31. Another important composer in the period of adapted music was Hafız Burhanettin, who also had a background in tekke music. He composed Turkish adaptations for 'The Tears of Love' (Damii' $a l-h u b b$ ), a film starring the Egyptian singer Abdulvahhab which gained immediate popularity when it was first shown in 1938, and these songs continued to be sung for years afterwards.

32. N. Karakayalı stresses the seriousness of the effort to popularize this kind of music. N. Karakayalı, 'Doğarken Ölen: Hafif Müzik Ortamında Ciddi Bir Proje Olarak Arabesk' [Stillborn: Arabesk as a Serious Project in the Context of Light Music], Toplam ve Bilim, No.67 (1995).

33. Zeki Müren, with his invention of T-shaped stage on which the contact between the artist and the audience first became possible, and extravagant costumes, is one of the most colourful TAM stars. Interestingly enough, it was Zennube, a record directly adapted from an Arab film which first catapulted him to fame. For a more detailed analysis see M. Nakip. 'Arabesk Musıkiye Dair' [On Arabesk Music], Töre, No.159 (1984), p.45.

34. Many films, particularly in the 1960 s, took their titles and even their plots from popular songs of the day.

35. M. Belge, 'Orhan Gencebay ile Görüşme' [An Interview with Orhan Gencebay], Yeni Gündem, No.14 (January 1985).

36. 'Anatolian Pop' is a delayed popular musical project of West-East synthesis. If the musical elite in the early years of the Republic had placed any importance on popular forms backing their cultural policies, perhaps they would not have failed so severely.

37. In a country where TRT had a monopoly on broadcasting, the only radio channel to defy the ban on Arabesk was another state-owned radio station, the Police Radio, which transmitted via short wave and thus could be heard in every sector of the country. The question as to why TRT could not interfere with this broadcasting deserves study.

38. E. Said, Orientalism (Harmondsworth: Penguin, 1978).

39. M. Belge et al., Atatürk Devrimleri, p.22. 